\title{
THE INTERNAL LOGIC OF ASSUMPTION OF EXECUTORY CONTRACTS
}

\section{David Hahn*}

Executory contracts are a pivotal element of bankruptcy, forming some of the most vital economic values for a debtor's business. Bankruptcy law allows a trustee to choose whether to assume an executory contract or to reject it. While this is well-settled statutory law, the theoretical foundations of assumption have been discussed rather sparingly. This paper aims to fill this gap by offering an analytical framework for the concept of assumption.

The paper explores the theoretical justifications for termination of a contract by an injured party upon its breach by the other party. It argues that the two primary justifications are the concern about recurring breaches and deterrence against potential breachers. I contend that both justifications lose force in the context of insolvency and bankruptcy and thus assumption of executory contracts is warranted. The judicial oversight in bankruptcy reduces the likelihood of recurring breaches. The deterrence rationale is relevant with respect to willful breaches, but less applicable with respect to no-fault, insolvency-related breaches. However, identifying the nature of a specific breach is practically difficult and lengthy. Given this difficulty on one hand and the importance of executory contracts to a debtor's reorganization on the other, I argue that bankruptcy law is correct in curtailing the injured party's termination rights and substituting them with a monetary remedy. That remedy is curing past defaults.

The paper defends the Bankruptcy Code's requirement of curing past defaults prior to assumption. I show that this prerequisite is justified both in debtor friendly and in creditor friendly bankruptcy regimes. In the former regime, curing past defaults combats the moral hazard of willful breaches. In the latter, it reflects a matter of fairness. According effective priority to the non-debtor party is defensible because that party is the only

* Senior Lecturer, Bar-Ilan University School of Law, Israel; J.S.D., NYU School of Law. I am grateful to Abraham Bell, Tsilly Dagan, Moshe Gelbard, Assaf Hamdani, Shachar Lifshitz, Jacob Nussim, Gideon Parchomovsky, and Arie Reich for helpful comments on earlier versions of this paper. 
claimant which is being legally compelled to perform future obligations to the debtor.

Finally, the paper discusses the roles of the bankruptcy courts in reviewing the assumption of executory contracts. I call for subjecting the priority status of the non-debtor party to the court's discretion. The courts should take into account that party's bona fide adherence to the terms of the contract during the bankruptcy case prior to upholding its priority status with respect to the payment of past contractual defaults.

\section{INTRODUCTION}

Executory contracts form an ongoing relationship between the parties so that at the time one party files for bankruptcy, the contract encompasses past and future obligations and rights between the parties. ${ }^{1}$ The fate of an executory contract may prove significant for the parties. The contract may represent an expected gain or an expected loss to the debtor. Consequently, its performance may enhance or impair the debtor's value and, derivatively, the ultimate return to the creditors.

Bankruptcy law addresses the important matter of executory contracts and provides for the assumption or rejection of such contracts. ${ }^{2}$ The right of the debtor to assume an executory contract circumscribes the non-debtor party's contract-law right to rescind that previously-breached contract.

The lengthy, detailed statutory provision has drawn the attention of commentators over the years. The literature on executory contracts has focused primarily on the interpretative aspects of the statute and has discussed also the notion of rejection of an executory contract. ${ }^{3}$

Somewhat surprisingly, the trustee's right to assume the contract, ${ }^{4}$ and

1. The relevant definition of executory contracts, occasionally put into question and yet almost uniformly recognized and adhered to by bankruptcy courts, is still the one proffered by Vern Countryman: "[A] contract under which the obligation of both the bankrupt and the other party to the contract are so far unperformed that the failure of either to complete performance would constitute a material breach excusing the performance of the other." Vern Countryman, Executory Contracts in Bankruptcy, Part I, 57 MinN. L. REV. 439, 460 (1973). Jay Westbrook has suggested abolishing the executoriness test and applying the bankruptcy rules to all uncompleted contracts. Jay L. Westbrook, A Functional Analysis of Executory Contracts, 74 MinN. L. REV. 227 (1989).

2. Bankruptcy Code, 11 U.S.C. § 365(a) [hereinafter Bankruptcy Code].

3. See, e.g., Michael T. Andrew, Executory Contracts in Bankruptcy: Understanding "Rejection," 59 U. Colo. L. REv. 845 (1988) (focusing on the rejection of an executory contract); Jesse Fried, Executory Contracts and Performance Decisions in Bankruptcy, 46 DUKE L.J. 517 (1996) (analyzing treatment of executory contracts in bankruptcy); George G. Triantis, The Effects of Insolvency and Bankruptcy on Contract Performance and Adjustment, 43 U. TORONTO L.J. 679 (1993) [hereinafter Triantis I] (noting the trustee's rights, including assumption, in bankruptcy); Westbrook, supra note 1.

4. For the purpose of brevity this article will use the term "trustee" as including both a trustee in bankruptcy under Chapter 7 of the Bankruptcy Code and the debtor-in-possession 
more specifically, the theoretical foundation underlying this right, has been relatively overlooked in the literature. Whether a trustee should be entitled to assume a previously breached contract, and if so, under what conditions, are questions which to date have been barely analyzed.

This article aims to enrich the literature on assumption of executory contracts and establish an analytical framework for its understanding. The contribution of this paper is threefold. First, it refutes simplistic contract law arguments supporting the termination of a contract breached by an insolvent debtor. The article argues that the rationales underlying the remedy lose force in the environment of insolvency and bankruptcy. Thus, curtailing the termination of pre-bankruptcy breached executory contracts and facilitating their continuance is normatively justified. Secondly, the paper offers a normative justification for the Bankruptcy Code's requirement that assumption of executory contracts be preceded with the curing of past defaults. It explains the curing of past default as a gentler alternative to termination of the contract. Given the importance of executory contracts to the successful reorganization of a debtor, this alternative is more adequate.

Finally, this article offers an amendment of the current law on executory contracts. The article calls for authorizing a bankruptcy judge, upon assumption of the contract, to deny the non-debtor party payments for pre-bankruptcy breaches it has suffered in circumstances where that party stalled and did not cooperate with the debtor party during the bankruptcy case. This would encourage and incentivize non-debtor parties to perform their obligations under an executory contract in good faith. As a result, it may enhance the value of such contracts for the debtor and its creditors as a whole.

This article continues as follows. Part II examines the rationales underlying the remedy of rescission upon a breach of contract. It discusses two primary rationales. The first is the need to protect the non-breaching party from the potential of recurring breaches by the breaching party. The second rationale is ex ante deterrence against potential breachers.

Part III will examine the survival of executory contracts through the lens of insolvency and bankruptcy. This part will first establish the importance of executory contracts to the overall operation of a debtor's business and its chances of successful reorganization. Subsequently, it shall challenge the right of termination in bankruptcy and argue that it should be qualified. To support this argument, I will show that the two underlying rationales of termination are relatively weak in the context of insolvency and bankruptcy.

under Chapter 11 thereto. See also Bankruptcy Code $\S 1101(1)$ (defining a debtor in possession). 
The concern about recurring breaches is mitigated as a result of the superseding of the debtor's management by a court-appointed trustee or by the bankruptcy court's oversight over the operations of the debtor in the case.

The deterrence rationale is less applicable with respect to no-fault breaches. In a creditor-friendly bankruptcy regime it is likely that most breaches upon insolvency will be no-fault breaches. In a debtor-friendly bankruptcy regime breaches may also be a result of opportunistic, willful behavior of the debtor. It would be lengthy and costly to litigate and differentiate between the different types of breaches. Thus, an overinclusive remedy is more practical.

Given the importance of executory contracts to the policy of bankruptcy on one hand and the irreversibility of termination on the other, Part III concludes that a softer alternative is preferable-qualifying the termination of the contract, subject to the requirement that the debtor cure its past defaults prior to assumption.

Part IV follows and examines closely the curing of past defaults as a prerequisite for assumption of an executory contract. The discussion supports this requirement both in debtor-friendly and in creditor-friendly bankruptcy regimes. In the former, curing past defaults combats moral hazard. In the latter, curing past defaults is a matter of fairness and is in accord with bankruptcy law's distributional policy. A party to an executory contract is the only person compelled to actively continue its ongoing relationship with the debtor. This idiosyncratic position justifies according special protection to that party, including the curing of past breaches.

Finally, Part V focuses on timing and priority. With respect to timing, it supports the Bankruptcy Code's delaying of the trustee's decision whether to assume an executory contract to an advanced phase in the administration of the bankruptcy case. To facilitate assumption, at the inception of the case the non-debtor party must be subjected to the automatic stay. As for priority, it is hereby suggested that despite the defacto priority the non-debtor party enjoys upon assumption of the contract by the debtor, this priority ought to be discretionally qualified by a bankruptcy court. Whenever the non-debtor party stalls its performance of the contract in bad faith during the administration of the case, prior to assumption, the judge may order that its entitlement for payments curing past defaults will lose priority and be paid as an unsecured claim. Giving this power to the bankruptcy court will properly incentivize the non-debtor party to carry forward the contract uninterrupted for the benefit of the debtor and its creditors as a whole. 


\section{THE RATIONALE OF TERMINATION}

Assume that prior to the commencement of its insolvency case the debtor defaults on a payment and thereby breaches its contract with another party. In most contracts, non-payment by a purchaser of a product or service is defined as a material breach, entitling the non-breaching party to terminate the contract. ${ }^{5}$ The basic premise of contract law is that when there has been a fundamental breach of contract, the only party which deserves the support and protection of the law is the party injured by the breach. ${ }^{6}$ Contract law affords the non-breaching party the right to seek the remedy of its choice and, subject to certain doctrines, will grant its wish. The non-breaching party can compel the breaching party to perform the contract by means of an order of enforcement or it can choose to terminate the contract, sever its legal relations with the breaching party, and collect damages. From the perspective of contract law, termination of the contract by the non-breaching party is an appropriate and justifiable action.

This part examines the underlying rationale justifying the remedy of rescission upon the breach of a contract. Theoretically, one may fathom that contract law would limit the rights of the non-breaching party to monetary damages to make it whole, yet compel it to perform its unperformed obligations under the contract nonetheless. The remedy of termination would not be sanctioned under the law at all. But contract law does provide the non-breaching party the right to terminate. The justification of this remedy is pertinent to executory contracts. These contracts entail a number of stages of performance by each of the parties to the contract. Termination of the contract prevents the creation of any economic value that potentially exists in its subsequent stages.

To be sure, in contracts where each of the parties is required to comply with one obligation only, for example, where a person sells a parcel of land to another, non-performance of an obligation by one party is inextricably linked to the obligation owed to it by the other party.

5. See Canefield v. Reynolds, 631 F.2d 169, 178 (2d Cir. 1980) (declining to extend the remedy of rescission to the non-breaching party in circumstances of non-material breach); see also Eric G. Andersen, A New Look at Material Breach in the Law of Contracts, 21 U.C. DAvis L. REv. 1073, 1074 (1988) (setting forth the criteria that distinguish material breach from any other breach of contract).

6. The copious literature dealing with breaches is overwhelmingly focused on the rights, remedies, and damages of the non-breaching party, whereas the ramifications of the breach on the breaching party are mostly ignored. The classic expression of the courts' indifference towards the interests of the breaching party is Justice Harris' famous statement that "If he (the promisor,- DH) has engaged . . . he cannot . . . innocently depart from his contract. If he fails to perform when the requirement is plain, and when he can perform if he will, he has no right to call upon the court to make a new contract for him; nor ought he to complain if the law leaves him without remedy." Smith v. Brady, 17 N.Y. 173, 203-04 (1858). 
Accordingly, in a contract which requires one-time performance of an obligation, it is clear that non-performance on the part of the breaching party will also relieve the non-breaching party, which has been injured by the breach, from performing its contractual obligation. ${ }^{7}$ The focus of the discussion herein is thus executory contracts that require ongoing performance from both parties.

The remedy of rescission may be justified either as a measure of protection against further breach of the contract or as an ex ante deterrence against breach of contract. These justifications are discussed below.

\section{A. Protection against Further Breach}

In light of the infringement already committed by the breaching party, there is a higher probability that this party will breach the contract again in the future. In other words, the current breach may indicate a desire or propensity on the part of the breaching party to not comply with the terms of the contract it has undertaken. Accordingly, the law seeks to protect the non-breaching party and safeguard it against a further breach which the breaching party may commit and thereby cause it additional damage in the future. ${ }^{8}$ The remedy of rescission is the legal method for sparing the nonbreaching party, in advance, any exposure to future breaches of the contract by the breaching party. It places a cap on the losses suffered by the nonbreaching party based on the current breach.

\section{B. Ex ante Deterrence against Breach}

Another possible reason for the remedy of rescission is that severing the relations between the contracting parties henceforth may act as an efficient deterrent to potential breaching parties and cause them to reconsider prior to breaching. If a potential breaching party knows, prior to committing the breach, that the breach will preclude it from enjoying the future benefits of the contract, it will think twice before committing the breach. Every potential breaching party must realize that its action will require it not only to compensate the injured party for the past breach, but

7. This statement is also true where the contract has been breached by reason of insolvency. Thus, for example, if prior to becoming insolvent, the insolvent party entered into a contract for the purchase of property from another party, the receiver cannot ask the other party to transfer the property or title thereof to him without paying the full contractual consideration in exchange. E. ALLEN FARNSWORTH, 3 FARNSWORTH ON CONTRACTS 565 (3d ed. 2004); SAMUEL WiLLisTON, Williston ON CONTRACTS $§ 45: 18$ (4th ed. 2009).

8. Barry E. Adler, The Law of Last Resort, 55 VAND. L. ReV. 1661, 1670 (2002). This rationale is particularly pertinent to the doctrine of anticipatory breach. Roehm v. Horst, 178 U.S. 1, 19 (1990); Howard O. Hunter, MOdern LAw OF CONTRACTS § 12:1, $14: 33(2009)$. 
also to forfeit future profits which it seeks to gain from the contract.

In response to the fear of an efficient breach of a contract, a nonbreaching party is entitled to augmented damages, which will deprive the breaching party of any alternative profit that it might otherwise have gained from its calculated repudiation of the contract. ${ }^{9}$ That is, the law prevents the potential breaching party from benefiting from its own calculated actions which run afoul with the fundamental norm of contract law - to keep good one's legal promise. Yet the remedy of augmented damages fails to deter a party from committing a calculated breach in circumstances where it is interested in continuing the performance of the breached contract. For example, damages alone may not deter a lessee from not paying its monthly rent in circumstances where the lessee is interested in continuing to use the leased property. An award of damages merely compels it to pay what is required of it in the first place under the original lease. ${ }^{10}$ In the absence of the remedy of rescission, the potential breaching party might regard it as worth its while to take a risk and breach the contract. ${ }^{11}$ The potential breaching party might calculate that the non-

9. Richard R.W. Brooks, The Efficient Performance Hypothesis, 116 YALE L.J. 568, 573-74 (2006); Melvin A. Eisenberg, The Disgorgement Interest in Contract Law, 105 Mich. L. REV. 559 (2006); Gareth Jones, The Recovery of Benefits Gained from a Breach of Contract, 99 L. Q. Rev. 443 (1983); Andrew Phang \& Pey-Woan Lee, Restitutionary and Exemplary Damages Revisited, 19 J. ConTRACt L. 1, 39 (2003). Cf. FH 20/82 Adras Bldg. Material Ltd. v. Harlow \& Jones Gmbh, 42(1) IsrSC 221, 267-268 (1988), reprinted in 3 RESTITUTION L. REV. 235 (1995).

10. Even under a no-rescission regime, there may be several factors that may mitigate a party's inclination to deliberately breach the contract. First, the contract may provide that the damages paid by the breaching party carry increased interest rates as a penalty intended to reduce the desirability of the breach. Secondly, the potential breaching party should factor the potential incurring of litigation costs and attorney's fees should the aggrieved party pursue full-scale litigation. Finally, awarding punitive damages may deter deliberate breaches. It is true that courts are authorized to impose punitive damages which, as the name suggests, are thought of as a means of deterrence. Texaco, Inc. v. Pennzoil, Co., 729 S.W.2d 768, 864 (Tex. App. 1987) ("Where the conduct of a party is of such a nature that similar behavior should be discouraged, the court can award punitive damages."); see also Pey-Woan Lee, Contract Damages, Corrective Justice, and Damages, 70 Modern L. Rev. 887 (2007) (describing contract damages as a form of punitive response to redress moral injury to another party). However, the remedy of punitive damages is by far more readily available upon tortious conduct than due to a breach of a contract. See Dorsey D. Ellis, Jr., Fairness and Efficiency in the Law of Punitive Damages, 56 S. CAL. L. REv. 1, 17 (1982) (recognizing the role of insult in explaining the allowance of punitive damages in limited circumstances of breach such as breach of promise to marry); Timothy J. Sullivan, Punitive Damages in the Law of Contract: The Reality and the Illusion of Legal Change, 61 MinN. L. REV. 207 (1976-77) (restating the presumption that punitive damages are not available in the standard action for breach of contract). Awarding over-compensatory damages for willful breaches is another method to combat deliberate breaches. Oren Bar-Gill \& Omri BenShahar, An Information Theory of Willful Breach, 107 MicH L. REV. 1479 (2009).

11. The discussion in the main text focuses on the efficacy of legal remedies to incentivize the parties to perform their contractual obligations. There may be alternative, 
breaching party would settle the case for partial payment. Alternatively, the non-breaching party may find it difficult to prove its case with the existing evidence. In the worst-case scenario for the potential breaching party, if its counter-party were to succeed in its claim for damages, the breaching lessee would eventually be compelled to pay the contractual payments under the lease. Thus, had contract law provided that the exclusive remedy for a breach of contract was monetary damages, there would be circumstances where parties to contracts would calculate and find it worthwhile to breach the contract deliberately. ${ }^{12}$ Absent the remedy of rescission parties would be more vulnerable to calculated breaches. This would undermine the integrity of contracts and their efficacy.

The remedy of rescission can provide an effective deterrent against breaches of contracts. Where the breach of contract results in depriving the potential breaching party of its future contractual profits, apart from the damages due to the non-breaching party, it thwarts the profitability of the breach of contract in advance. ${ }^{13}$ The remedy of rescission and the remedy

informal measures that affect a party's incentives and cause it to perform. Such measures may be self-enforcing actions taken by the other party, or adherence to market and social norms in a given community or industry. See generally John McMillan \& Christopher Woodruff, Private Order under Dysfunctional Public Order, 98 MicH. L. Rev. 2421 (2000) (examining the role of social networks and informal measures in substituting for the formal legal system in transition economies). For a discussion of the interrelations between the legal and non-legal incentives to perform contractual obligations see Ariel Porat, Enforcing Contracts in Dysfunctional Legal Systems: The Close Relationship Between Public and Private Orders, 98 Mich. L. REV. 2459, 2469-77 (2000).

12. See Stewart Macaulay, An Empirical View of Contract, 1985 Wis. L. REV. 465, 46970 (finding that often contract damages are under-compensatory).

13. As follows from the main text, the remedy of rescission is linked to the remedy of enforcement. The two are opposing but complementary remedies for the purpose of implementing the goal of deterrence. As a matter of principle, law and economics scholars are not daunted by efficient breaches of contract and accordingly have reservations about the remedy of enforcement. John H. Barton, The Economic Basis of Damages for the Breach of Contract, 1 J. LegAL STUD. 277 (1972); Robert Birmingham, Breach of Contract, Damage Measures, and Economic Efficiency, 24 RuTGERS L. REV. 273 (1970); Charles J. Goetz \& Robert E. Scott, Liquidated Damages, Penalties and the Just Compensation Principle: Some Notes on an Enforcement Model and a Theory of Efficient Breach, 77 Colum. L. Rev. 554 (1977); Gwyn D. Quillen, Contract Damages and Cross-Subsidization, 61 S. Cal. L. Rev. 1125 (1988); Richard Craswell, Contract Remedies, Renegotiation, and the Theory of Efficient Breach, 61 S. CAL. L. REv. 630 (1988). These scholars believe that enforcement is only justified when the non-breaching party is injured because it is precluded from obtaining a "unique" product, i.e. a product in respect of which the cost of determining its personal value to the injured party is particularly high in view of the few market transactions relating to the product. The remedy of enforcement saves the parties and the judicial system the cost of valuing the damage to the injured party. See Anthony T. Kronman, Specific Performance, in The ECONOMics of Contracts LAW 181, 188-89 (Kronman \& Posner eds., 1979). According to this economic approach, the purposes of the remedies of enforcement and rescission are compatible. In a similar vein to the aforementioned approach to enforcement, it has been argued that rescission compensates the 
of monetary damages thus serve different goals. The latter is primarily a corrective remedy. It compensates for losses suffered by the non-breaching party upon a breach of the contract. The former generates deterrence and reduces the probability of a breach ex ante. ${ }^{14}$

\section{TERMINATION IN BANKRUPTCY}

Part II outlined the underlying justifications for a party's right to rescind its contract following a contract breach by the other party. This part turns its attention more specifically to contracts breached upon the insolvency of the breaching party. The discussion herein will first emphasize the economic importance of executory contracts for successful corporate reorganizations. This will be followed by an analytical challenge of the justifications for rescission through the lens of insolvency and bankruptcy.

\section{A. The Importance of Executory Contracts}

Executory contracts may be extremely important to an insolvent company. Often the continuation of certain contracts will be the basis for the entire business operation of the debtor. For example, a contract under which the debtor obtains communication infrastructure services from its telecommunication services provider is a contract without which it is doubtful whether the debtor can continue to conduct its business. As a practical matter, the continuation of the contract is critical because the costs and time entailed in negotiating and entering into an alternative contract might be significant. In these circumstances, entering into an alternative contract is an impracticable solution for the debtor, in view of its penurious situation. A debtor that becomes insolvent lacks two things: time and liquid funds. Any action required to keep its business alive which consumes these two resources is doomed to failure.

To illustrate the practical importance of preserving executory contracts, consider a long-term lease. The leased property may be essential to the business of the debtor. The location of the property, its accessibility to suppliers and customers, the relatively cheap rental rates, low local tax

injured party for its personal damage by restoring the parties to their pre-contractual position in circumstances where the cost of determining its personal damage in a hearing on monetary damages is particularly high. George L. Priest, Breach and Remedy for the Tender of Nonconforming Goods under the Uniform Commercial Code: An Economic Approach, 91 HARV. L. REV. 960, 963-68 (1978).

14. Eric Posner argues that the termination of a contract by the aggrieved party is an effective alternative remedy to pure monetary damages in situations where the breaching party is judgment-proof. Eric A. Posner, Fault in Contract Law, 107 MicH. L. REV. 1431, 1439-40 (2009). 
rates and more often turn the leased property into a central resource of the debtor's business. Accordingly, continuation of the lease or its termination will have considerable ramifications for that debtor's economic future. ${ }^{15}$

Reorganizing a financially distressed debtor requires first and foremost the continuation of its business operations uninterrupted. ${ }^{16}$ Any stoppage or delay in the routine business turnover will impair the practical ability to rescue the debtor from its financial crisis and return to its ordinary course of business. ${ }^{17}$ Operating a going concern involves the business suppliers on one hand and its customers on the other. Without the everyday supply of products and services, and without sales, the business will collapse despite any legal efforts to the contrary. Thus, a legal regime that aims to salvage financially ailing firms, facilitate their reorganization, and enhance the collective value available for the creditors ought to qualify the termination of executory contracts to which a debtor is a party. This proposition is in accord with the empirical study conducted by Djankov, Hart, McLiesh, and Shleifer, according to which qualifying the right to terminate contracts improves the efficiency of corporate insolvency. ${ }^{18}$

However, curtailing the right of rescission appears to be at odds with the fundamental principles of contract law. Contract law entitles an aggrieved party to terminate the contract upon its breach as a matter of right. The remainder of this part and the next part will address this

15. Leasing property is characteristic of many retail businesses, especially today in light of the concentration of consumer purchasing power in shopping malls. These malls are generally owned by real estate companies, which lease out all the shops in their shopping malls. Many retail chains therefore conduct the bulk of their activities in leased properties located in the various shopping centers situated around the country. Smith v. Hoboken R.R. Warehouse, 328 U.S. 123, 132 (1946); Coleman Oil Co. v. Circle K Corp. (In re Circle K Corp.), 190 B.R. 370, 376 (B.A.P 9th Cir. 1995); Ira L. Herman, The Impact of Bankruptcy on Commercial Leasing Transactions, in Negotiating Commercial Leases 517, 530 (2008); Daniel J. Bussel \& Kenneth N. Klee, Recalibrating Consent in Bankruptcy, 83 Ам. BANKR. L. J. 663, 739-40 (2009).

16. At the inception of a reorganization case, the automatic stay against the creditors is intended to preserve the debtor's property and facilitate their continued use uninterrupted. Bankruptcy Code $\S \S 362,363$. United Sav. Ass'n of Texas v. Timbers of Inwood Forest Assocs., 484 U.S. 365 (1988); In re Siciliano, 13 F.3d 748, 750 (3d Cir. 1994); In re Pettit, 217 F.3d 1072, 1077 (9th Cir. 2000); Computer Commc'ns, Inc. v. Codex Corp., 824 F.2d 725, 729 (9th Cir. 1987); Tringali vs. Hathaway Machinery Co., 796 F.2d 553 (1st Cir. 1986); In re Franklin Equip. Co., 416 B.R. 483, 522 (Bankr. E.D. Va. 2009); Ann H. Spiotto, The Ultimate Downside of Outsourcing: Bankruptcy of the Service Provider, 11 Am. Bankr. Inst. L. Rev. 47, 67-68 (2003); Marc Forsythe, United Savings Ass'n v. Timbers of Inward Forest Associates, Ltd., 20 PACIFIC L.J. 1309, 1311-15 (1989).

17. John D. Ayer, Michael Bernstein \& Jonathan Friedland, An Overview of the Automatic Stay, 22-10 Am. BANKR. Inst. J. 16 (2003-2004); Michael L. Cook \& Jessica L. Fainman, The Bankruptcy Code's Automatic Stay, 905 PraCtising L. InST. 421, 429-30 (2008).

18. Simeon Djankov, Oliver Hart, Caralee McLiesh \& Andrei Shleifer, Debt Enforcement Around the World, 116 J. POL. ECON. 1105 (2008). 
apparent tension.

\section{B. Subsequent Breaches in Bankruptcy}

In Part II above I argued that one goal of the remedy of rescission is to protect the non-breaching party from successive, future breaches of the contract by the breaching party. That is, the law assigns a low probability to the future performance of the contract in light of its past infringement by the breaching party. Yet this probabilistic assumption is predicated on two factors without which the future protection goal of rescission loses its persuasiveness.

The first factor that contributes to the low probability of future performance upon a breach of a contract is that the decision-maker on the breaching party's side before and after the breach is identical. Nonetheless, this outcome is only likely so long as the same people who functioned as the decision-makers on behalf of the insolvent party at the time of the past breach of the contract remain the decision-makers upon that party's bankruptcy case. The second factor is the assumption that the operating and financing terms of the breaching party have not improved after the breach. Thus, its failure to perform once may indicate an increased risk for the counter-party that defaults by the breaching party may recur.

These two underlying factors change dramatically in bankruptcy. First, the commencement of a bankruptcy case alters the decision-making in the debtor firm. Although in Chapter 11 the management remains in office as debtor-in-possession, ${ }^{19}$ its operations and decision-making is nonetheless subject to the close scrutiny of the bankruptcy court. A debtorin-possession bears the functions of a trustee ${ }^{20}$ and interacts throughout the case with the creditors' committee. ${ }^{21}$ Under such terms of operation, the management is less flexible and thus it is unlikely that it will voluntarily rebreach the executory contract without an explicit advance approval of the court. The difference in the decision-making in the debtor upon bankruptcy is even more conspicuous under Chapter 7, where a newly appointed trustee replaces the management. ${ }^{22}$ This change in the operating conditions reduces the concern of repeated breaches by the debtor party.

The second factor that leads to a low probability of future performance is the understanding that an insolvency-related breach signifies failure to comply with the debtor's contractual obligations because of its lack of

19. Bankruptcy Code $\S 1101(1)$.

20. Id. at $\S 1107(\mathrm{a})$.

21. Id. at $\S \S 1102,1103(\mathrm{c})$.

22. In other jurisdictions, trustees are appointed even in reorganization cases. See David Hahn, Concentrated Ownership and Control of Corporate Reorganisations, $4 \mathrm{~J}$. CORP. L. STUD. 117 (2004). 
economic resources. When the debtor lacks sufficient cash, it will fall into arrears in its payments to the counter-party notwithstanding its contractual commitments. Nonetheless, within bankruptcy, the operating conditions of the insolvent firm may improve, even if only temporarily. Upon the commencement of a case, the appointed debtor-in-possession or trustee will often be able to raise new financing for the routine activities of the insolvent party. This fresh financing is unavailable to the debtor prior to the commencement of the case. ${ }^{23}$ Such financing may produce the requisite cash flow for the debtor's contractual payment obligations henceforth.

Given these two differences between the operation of a debtor outside and inside bankruptcy, the fact that the contract has been breached in the past, prior to the bankruptcy case, does not entail a heightened probability that this contract is prone to future breach during the bankruptcy case. ${ }^{24}$ To be sure, executory contracts may be breached inside bankruptcy. There are no guarantees that this will not occur. Yet, the likelihood of a future breach depends on the facts of each case. That is, whether the debtor will default on the contract in bankruptcy depends on the particular economic and financial situation of that specific debtor. The past contractual history of the debtor is of little significance in calculating the risk of future breach. Thus, to the extent that the debtor-in-possession or trustee can convince the court that future performance of the debtor's contractual obligations is feasible, the court should not attach much importance to the past breach as a factor in calculating the probability of future performance of the contract. ${ }^{25}$

\section{No Fault Breaches in Insolvency}

The second justification for the rescission remedy for breach of contract is deterrence against potential breaches. However, this justification is less applicable with respect to executory contracts breached

23. For a discussion of the facets of this DIP financing see David A. Skeel Jr., Creditors' Ball: The "New” New Corporate Governance in Chapter 11, 152 U. PA. L. REV. 917 (2003); George G. Triantis, A Theory of the Regulation of Debtor-in-Possession Financing, 46 VAND. L. REV. 901 (1993) [hereinafter Triantis II].

24. Indeed, in the pre-Code years, the mere commencement of bankruptcy was recognized as anticipatory breach of the contract. See, e.g., Central Trust Co. of Illinois v. Chicago Auditorium Ass'n, 240 U.S. 581 (1916). However, the trustee's privilege of assuming or rejecting executory contracts under the Code has made this interpretation incompatible with statutory law. See Vern Countryman, Executory Contracts in Bankruptcy, Part II, 58 MinN. L. Rev. 479, 519-20 (1974); Carl N. Pickerill, Executory Contracts Re-Revisited, 83 AM. BANKR. L. J. 63, 70 (2009).

25. Within the framework of the court's discretion whether to qualify the right of termination of the contract or not, the court can require the debtor-in-possession or trustee to provide adequate assurance of future performance of the contract when assuming the contract. See Bankruptcy Code $\S 365(b)$. 
by reason of a debtor's insolvency. ${ }^{26}$ Deterrence measures are relevant and effective only against calculated and willful breaches. As a deterrent remedy aimed at frustrating bad faith acts, rescission is intended to eradicate the potential breaching party's desire to infringe the contract.

A party to a contract may breach the contract either willingly or without fault. Breaches by virtue of insolvency are often no-fault breaches. ${ }^{27}$ Once a debtor faces insolvency and is cash-constrained, contractual payment breaches will occur due to the debtor's inability to pay, regardless of its willingness to uphold its contractual obligations. Whether the payments are leasehold payments, wages payments to employees, or payments to its suppliers for goods and services, the dire state of the insolvent party compels it to infringe its contract. In such poor circumstances, the thought or desire to breach is simply immaterial. Terminating contracts breached by reason of financial disability will not reduce the likelihood of such breaches. If the debtor is financially constrained and unable to pay, the threat that the contract may be terminated by the counter-party will not cause the debtor to pay nonetheless. The debtor will default regardless of the legal consequences. Accordingly, to the extent the breach was an insolvency-related, no-fault breach, allowing the non-breaching party to terminate the executory contract serves no deterrence goal. ${ }^{28}$

\section{Willful Breaches, Bankruptcy and Moral Hazard}

Its insolvency state notwithstanding, a party may nonetheless breach the contract willfully. As it becomes insolvent and thus judgment-proof, a party is more susceptible to calculated breaches. ${ }^{29}$ As an insolvent party, it

26. In the general contract law discourse, Ariel Porat has argued that it is justifiable to moderate the absolute rights of the aggrieved party by introducing considerations of comparative fault. GuENTER TREITEL, THE LAW OF CONTRACT, 982 et seq. (11th ed., 2003); Ariel Porat, A Comparative Fault Defense in Contract Law, 107 Mich L. REv. 1397 (2009).

27. Reconciling willful breaches with the qualification of the rescission remedy in bankruptcy is discussed in Part III.E, infra.

28. Some courts hold corporate agents personally liable for a corporation's violation of the Fair Labor Standards Act's requirement for payment of minimum wages and overtime compensation, even where the corporate employer entered bankruptcy. See Boucher v. Shaw, 2009572 F.3d 1087, 1094 (9th Cir. 2009) (finding managers of bankrupt corporation individually liable under FLSA) (citing Donovan v. Agnew, 712 F.2d 1509, 1511, 1514 (1st Cir. 1983)); Chung v. New Silver Palace, 246 F.Supp. 2d 220, 226 (S.D.N.Y. 2002) (finding the non-debtor defendants individually liable under FLSA). The courts discuss primarily the question whether the automatic stay in bankruptcy enjoins actions against third parties such as the corporate agents. The courts do not discuss, however, the fundamental argument raised in the main text-whether insolvency-related, no-fault breaches merit the same legal sanctions as willful violations of a contract or the law.

29. Steven Shavell, The Judgment Proof Problem, 6 InT'L Rev. L. \& Econ. 45 (1986). 
will not pay all the damages to the other party. Thus, the debtor party will not internalize all the costs of its breach. ${ }^{30}$ Moreover, qualifying the right of the non-debtor party to terminate the contract under bankruptcy law may exacerbate this moral hazard. Apparently, the insolvent party would be provided with an incentive to deliberately breach the contract and enter bankruptcy shortly after. A voluntary bankruptcy filing would immunize the breaching party from termination.

The severity of this moral hazard differs based on two factors. These factors are (a) the ease of filing for bankruptcy and (b) the personal cost of bankruptcy to the debtor's management. To the extent a voluntary filing for bankruptcy requires the meeting of certain prerequisites - most notably litigating and convincing the court that the debtor is insolvent - a deliberate breach of an executory contract bears a risk to the potential breaching party. The financially constrained party must take into account the fact that the counter-party may terminate the contract quickly after the breach, before the debtor is able to resort to bankruptcy. In this respect, the fundamental idea of rescission as a deterrent against willful breach applies forcefully. Until bankruptcy has commenced, the injured party's right of termination is unqualified whatsoever. Accordingly, if the potential breaching party wishes to continue to enjoy the fruits of its executory contract, it must be careful to avoid willful breaches. ${ }^{31}$

The personal cost of a bankruptcy filing concerns the control of the debtor's operations upon the commencement of bankruptcy. To the extent the commencement of bankruptcy entails the appointment of a courtappointed trustee, the debtor's management will pay a heavy personal price for filing. By filing for bankruptcy the management effectively abdicates. ${ }^{32}$ It is unlikely that the management of a financially distressed debtor firm will decide to breach an executory contract willfully and file for bankruptcy shortly thereafter to save the contract from termination. Sacrificing their offices and jobs as a direct result of willful breaches is too heavy a price to pay.

It follows then, that in jurisdictions where the filing for bankruptcy

30. George Triantis discussed another moral hazard created by the bankruptcy law's executory contracts rules. Triantis examines the rule allowing a debtor to reject (that is, breach) an executory contract (that hasn't been breached prior to bankruptcy) while limiting the non-debtor party to damages as merely an unsecured claimant. Triantis argues that this increases the risk of overinvestment in contracts by the prospective insolvent party and incentivizes the debtor to breach in bankruptcy. Triantis I, supra note 3. Unlike Triantis's piece, this essay focuses on the assumption of executory contracts that have been breached prior to the commencement of bankruptcy.

31. See George G. Triantis, Jumping Ship: Termination Rights in Bankruptcy: The Story of Stephen Perlman v. Catapult Entertainment, Inc., in BANKRUPTCY LAW STORIES 55, 68 (Robert K. Rasmussen ed. 2007).

32. Hahn, supra note 22. 
protection consumes time and requires meeting preconditions, and where that filing entails change of personnel at the helm, the moral hazard of willful breaches upon insolvency is insignificant. U.S. bankruptcy law, however, smoothes the path to voluntary bankruptcy and facilitates quick and simple filings. ${ }^{33}$ Also, under Chapter 11, a debtor's management remains in office and functions as a debtor-in-possession and no trustee is appointed. ${ }^{34}$ Given this legal environment, the potential moral hazard of willful breaches upon contemplating a bankruptcy filing cannot be overlooked.

\section{E. Qualifying Termination in Bankruptcy}

The main challenge the courts must face is differentiating between nofault insolvency-related breaches and willful, opportunistic breaches. Only the latter raise the concern of under-compensatory remedies. In principle, combating willful breaches may justify the remedy of rescission. It is, however, impractical for the courts to determine successfully which breaches are calculated and deliberate and which are not. ${ }^{35}$ Thus, applying the rescission remedy is necessarily over-inclusive. ${ }^{36}$ It would allow the non-breaching party to terminate a breached contract regardless of the nature of the breach. Termination is irreversible. ${ }^{37}$ Given the economic importance of certain executory contracts to a debtor's operations and to its chances of reorganization, termination as a result of no-fault breaches would therefore constitute an economic waste.

To overcome the over-inclusiveness of termination and its adverse effects to the policy of reorganization, the law should implement a softer

33. Bankruptcy Code $\S 301$.

34. Id at $\S \S 1101,1104,1107$ (trustee shall be appointed only for cause; otherwise the debtor-in-possession shall control the debtor's operations).

35. Triantis I, supra note 3, at 701.

36. See Robert E. Scott, A Relational Theory of Default Rules for Commercial Contracts, 19 J. Legal STUD. 597 (1990) (discussing strict and lenient enforcement of contractual obligations); Robert E. Scott, Conflict and Cooperation in Long Term Contracts, 75 CAL. L. REV. 2005 (1987) (same).

37. One may fathom reversing pre-bankruptcy terminations retroactively upon the commencement of the debtor's bankruptcy, in a process similar to the retroactive avoidance of a preference under Bankruptcy Code $\S 547($ b). However, given the courts' difficulties in differentiating willful and no-fault breaches, it is questionable whether this alternative would prove its worth. In addition, it seems to be far-reaching and manifestly impractical to renew an agreement containing additional affirmative obligations that have not yet been fulfilled months after this agreement has already been terminated and after the parties have gone their separate ways. This is different from avoiding the transfer of property, which does not require the creditor and the insolvent debtor to perform any additional, unfulfilled obligations in between. When avoiding the transfer of property to a creditor all that is required is the paying back of the value which was transferred by the debtor in the past and nothing more. 
remedial system for pre-bankruptcy breaches of executory contracts. The softer and more balanced approach is to qualify the non-debtor's party to terminate the contract, but to require the debtor to cure its defaults as a precondition to assumption of the contract. ${ }^{38}$ Requiring the curing of past defaults prior to assumption effectively makes the non-debtor party whole while allowing the debtor party a second chance to salvage their contractual relationship. ${ }^{39}$ This is precisely the method that has been correctly implemented by the Bankruptcy Code. ${ }^{40}$ Curing past defaults is further discussed in the following part.

\section{CURING Past Defaults Prior to AsSumption}

Part III laid the case for assumption of an executory contract in bankruptcy notwithstanding its pre-bankruptcy breach by the debtor. To soften the qualification of the termination remedy the debtor must cure past defaults prior to assuming an executory contract. This part analyzes normative considerations both supporting and opposing the curing of past defaults by a debtor prior to assumption. ${ }^{41}$ It concludes that the arguments supporting the cure of past defaults outweigh the counter-arguments.

\section{A. $\quad$ Curing Defaults in DIP Regimes}

Part III raised the concern that in debtor-friendly insolvency regimes,

38. It is impossible to require the debtor-in-possession or trustee to cure all defaults on a contract at the stage of bankruptcy. Certain financial covenants typically found in loan instruments, such as maintaining stipulated financial ratios, will inherently be breached by reason of the debtor's insolvency. Default on such covenants cannot be cured while the debtor is in bankruptcy. The Bankruptcy Code identifies this problem and exempts such contractual defaults from cure prior to the assumption of an executory contract. See Bankruptcy Code $\$ 365(b)(2)$ (2010).

39. See Stefan Grundmann, The Fault Principle as the Chameleon of Contract Law: A Market Function Approach, 107 MicH. L. REV. 1583, 1598 (2009) (discussing the concept of a second chance that is given to a breacher of a contract under German law in contexts other than bankruptcy).

40. Bankruptcy Code $\S 365(a)$, (b) (2010). It has been noted in commentary that, notwithstanding this statutory provision, in practice the courts often require the counterparty to continue performing the executory contract even though the debtor has not cured its past defaults. See Lynn M. LoPucki \& George G. Triantis, A Systems Approach to Comparing US and Canadian Reorganization of Financially Distressed Companies, in Current Developments in InTERnational and Comparative Corporate Insolvency LAW 109, 132 (Jacob S. Ziegel ed. 1994). These authors note that this is also the legal state in Canada under the Companies' Creditors Arrangement Act, C-36.

41. More than a decade ago, Epstein and Nickles noted that the reasoning behind the legislature's requirement to cure past defaults as a precondition for assumption of an executory contract has not been persuasively explained and clarified. David G. Epstein \& Steve H. Nickles, The National Bankruptcy Review Commission's Section 365 Recommendations and the "Larger Conceptual Issues," 102 Dick. L. REV. 679 (1998). 
primarily those in which a debtor-in-possession controls the reorganization proceedings, there exists the moral hazard of willful breach of contract by insolvent parties. An insolvent party may breach the contract, even in circumstances where it has the ability to perform, and follow its own breach by a tactical voluntary commencement of bankruptcy. To the extent the termination of contracts is qualified in bankruptcy the debtor is contemplating having it both ways. It may breach the contract and still not suffer from its termination.

To ameliorate this moral hazard the debtor should be required to cure its defaults prior to asserting its right in bankruptcy to assume the executory contract. Curing the defaults is a soft alternative to termination. Both root out the debtor party's opportunistic incentives to breach. However, given the rigid and irreversible nature of termination, curing the defaults is the preferred remedy in bankruptcy.

To be sure, requiring the curing of defaults applies to all breached contracts. As discussed in Part III above, it is difficult and time consuming to litigate in bankruptcy court and distinguish between a willful breach and a no-fault insolvency-related breach. Thus, even the latter breach would require curing the default prior to its assumption. The assumption of executory contracts and the curing of defaults associated therewith take place, however, only at an advanced stage of the bankruptcy case. At that stage the debtor is expected to be able to meet this requirement. Thus, unlike the termination of the contract upon the inception of bankruptcy, the over-inclusiveness of this monetary remedy is unlikely to impair the bankruptcy case.

\section{B. Curing Defaults in Trustee Regimes}

I have argued earlier that in creditor-friendly bankruptcy regimes, where a trustee ousts the debtor's management, the moral hazard risk of calculated breaches upon insolvency is insignificant. ${ }^{42}$ It follows, then, that most breaches upon the insolvency of a debtor are likely to be no-fault insolvency-related breaches. Nonetheless, even in such a regime, conditioning the assumption of an executory contract on curing past defaults is justified. The justification is fairness.

In my view, it is unfair for the law to intervene in the parties' mutual contractual setting and force the non-debtor party, who has already suffered from the debtor's breach of the contract, to perform additional obligations to the debtor party without being first compensated for the loss it has already incurred as a result of the breach.

As analyzed in Part III above, it is indeed appropriate to curtail the

42. See supra Part III.A. 
non-debtor party's right to terminate where the termination achieves no purpose. Thus, once all past losses have been remedied any insistence of the non-debtor party to terminate the contract nonetheless ought to be based solely on concerns regarding the future performance of contract by the debtor. In bankruptcy, these concerns are allayed by the requirement to provide adequate assurance for future performance, which is approved by the court. ${ }^{43}$ Thus, no serious justifications for termination of the contract remain.

However, to the extent that pre-bankruptcy defaults are not cured by the trustee, the assumption of an executory contract has the effect of confining the non-breaching party to the contract notwithstanding its own economic losses. Where the non-breaching party has suffered a monetary loss as a result of the breach, there is justification for releasing that party from the contract in order to enable it to seek some compensation through alternative channels in the market. Relieving the non-debtor party from the contract allows that party to mitigate its losses by entering substitute profitable contracts, the performance of which has not been frustrated. ${ }^{44}$ The non-breaching party is a creditor of the debtor for past defaults. Assumption of the contract compels this creditor to continue performing its own contractual obligations notwithstanding the monetary loss it has already suffered. No such demand is imposed on any other creditor of the debtor, whether secured or unsecured. Creditors file proof of claims in respect of past and due claims. Some creditors enjoy priority of their claims by virtue of perfecting a security interest, ${ }^{45}$ asserting a right of setoff, ${ }^{46}$ or a statutory priority accorded to them. ${ }^{47}$ But none of these creditors

43. Bankruptcy Code $\S 365(\mathrm{~b})(1)(\mathrm{B})$ (2010). See also In re Fleming Companies, Inc., 499 F.3d 300, 305 (3d Cir. 2007); In re Family Snacks, Inc. 257 B.R. 884, 902 (B.A.P. 8th Cir. 2001); In re Everest Crossing, LLC No. 09-16664-FJB (Bankr. D. Mass. 2010) (as yet unpublished); In re Carlisle Homes, 103 B.R. 524, 538 (Bankr. D.N.J. 1988). Courts seem to be of the opinion that "[w]hat constitutes adequate assurance is a factual question determined on a case-by-case basis." In re Gen. Oil Distrib., 18 B.R. 654, 658 (E.D.N.Y. 1982). That assurance "will be adequate if performance is likely, i.e., more probable than not.” In re PRK Enters., Inc., 235 B.R. 597, 603 (Bankr. E.D. Tex. 1999). Somewhat less vaguely, the Fifth Circuit has held that courts should consider "whether the debtor's financial data indicate[s] its ability to generate an income stream sufficient to meet its obligations, the general economic outlook in the debtor's industry, and the presence of a guarantee." Texas Health Enter., Inc. v. Lytle Nursing Home, 72 Fed. Appx. 122, 126 (2003). See also William H. Schorling \& Robert P. Simmons, Adequate Protection for the Nondebtor Party to Executory Contracts and Unexpired Leases, 64 AM. BANKR. L.J. 297 (1990).

44. David W. Barnes \& Deborah Zalesne, A Unifying Theory of Contract Damage Rules, 55 Syracuse L. Rev. 495, 536-37 (2005); Thomas H. Jackson, Anticipatory Repudiation and the Temporal Element of Contract Law, 31 STANFORD L. REV. 69 (1978).

45. Bankruptcy Code $\S 724$ (2010).

46. Id. $\S 553$.

47. $I d . \S 507$. 
is required to perform any additional obligations to the debtor. They enjoy a right against the estate that is not accompanied by any continuous legal obligation on their side.

In contrast, by coercing the non-debtor party to an executory contract to continue its future performance without the prior curing of past defaults, the law forces that party to incur additional out-of-pocket expenses without first making the party whole. Thus, even though payment of past, prebankruptcy defaults to the non-breaching party effectively accords it priority over other creditors, ${ }^{48}$ this deviation from the principle of equality is justified in light of the economic price the non-debtor party suffers alone. $^{49}$ Coercing only this creditor to provide future resources to the debtor without fully compensating the creditor for losses it has suffered previously is unfair. It hurts the creditor in a fashion not shared by any other creditor.

\section{Violating the Principle of Equality?}

A pre-bankruptcy breach of an executory contract creates a monetary claim for damages for the non-debtor party. Absent any collateral to secure it, this claim is an unsecured claim. ${ }^{50}$ Bankruptcy law's fundamental principle of equality requires equal treatment of all unsecured claims. ${ }^{51}$ Departing from the principle of equality is only justified when there are proper policy reasons for preferring one creditor over another. Curing past defaults to the non-debtor party as a precondition for assuming an executory contract means that it will receive one hundred cents on the dollar $(100 \%)$ for pre-bankruptcy claims. Such a payment, at a time when other creditors are not paid in full, clashes with bankruptcy law's principle of equality of distribution.

The argument is that the non-debtor party must file a proof of claim

48. See infra Part IV.C.

49. My position, as explained here, relates only to contracts in which the mutual obligations are interconnected within the framework of a particular commercial transaction. It does not relate to a contract which concerns the entire relationship between the parties, such as an infrastructure contract in which one party undertakes to provide the other party both installation services and continuing maintenance services. If the party ordering these services has not paid for the installation of the infrastructure, this will not justify termination of the routine maintenance services by the provider. The installation service and the maintenance service are two separate services and should not be linked together ex post facto. See In re Payless Cashways, 230 B.R. 120 (B.A.P. 8th Cir. 1999); Matter of Executive Tech. Data Sys., 79 B.R. 276 (Bankr. E. D. Mich. 1987).

50. But see Steven L. Schwarcz, Rethinking Freedom of Contract: A Bankruptcy Paradigm, 77 Tex. L. REv. 515, 520, 574-75 (1999) (arguing that security interests are but one form of legal override of mandatory bankruptcy law and that pre-bankruptcy contracting may justify a similar condonation by the law).

51. Bankruptcy Code $\S 726(a)(2)$, (b) (2010). 
for its past payments like any other unsecured creditor of the debtor. At the stage of payment of all claims, the non-debtor party will be paid pro rata with all the unsecured creditors.

Moreover, even if the non-debtor party were entitled to terminate the contract absent curing of past defaults by the debtor, the non-debtor party would still incur the losses of the past defaults. It would not be allowed to collect its claim thereon. Thus, termination of the contract instead of continuing performance will not produce any money to the non-debtor party. In a bankruptcy setting, the monetary remedy of damages does not operate in conjunction with termination or performance. Therefore, curing past defaults awards the non-debtor party monetary damages it would not enjoy otherwise.

While this argument correctly identifies the distributional effect of curing past defaults, it nonetheless overlooks the fundamental difference between the non-debtor party and other creditors of the debtor. As discussed above, only the former is compelled to continue performing its contractual obligations in bankruptcy. ${ }^{52}$ This distinction merits in exchange the unique treatment of compensating the non-debtor party for past defaults. This does not violate bankruptcy law's policy of equality. Comparing the position of the non-debtor party to that of other unsecured creditors is simply comparing apples to oranges.

\section{Mutuality as a Quasi-security Interest}

A requirement to cure past defaults as a precondition for future performance emphasizes the reciprocity of obligations under a contract. The concept of reciprocity arises from the respect shown by contract law for the desire and interests of each contracting party to safeguard itself against a breach of contract by the counter-party. In other words, the concept of mutual obligations in a contract reflects a defense mechanism for the benefit of contracting parties. Under this understanding, the mutuality constitutes a security interest. ${ }^{53}$ Alas, the power of this quasisecurity interest is limited and, unlike a full scale security interest, cannot secure the non-debtor party in every circumstance. Thus, for example, if the breaching party is no longer interested in the continued performance of the contract, the intertwining of the correlative contractual obligations carries no advantage for the non-breaching party. It does not elevate its claim for breach of the contract to the level of a secured claim. ${ }^{54}$ Nonetheless, the argument is that in the circumstances under discussion, where the debtor-in-possession or trustee is interested in assuming the

52. See supra Part IV.B.

53. Schwarcz, supra note 50.

54. Bankruptcy Code $\S 365(\mathrm{~g})$ (2010). See also Westbrook, supra note 1. 
previously-breached contract and enjoying its value, the interdependence between all the contractual obligations can benefit the non-breaching party and act as a de facto security interest, enabling this party to fully recover its claim from the debtor.

The aspiration of every creditor to protect itself with security measures for payment is natural and understandable. However, in an insolvency scenario the private preferences of any party or creditor are superseded by the collective good of the creditors as a group. If private actions or contractual arrangements are to prevail in bankruptcy there must be substantive grounds of fairness or efficiency to justify such primacy. Absent such independent justifications, bankruptcy law cannot accord priority to any specific creditor notwithstanding a private contract purporting to solidify the counter-party's position vis-à-vis the debtor and its other creditors. ${ }^{55}$ Thus, identifying the mutuality of contractual obligations as a security mechanism in its own fails to advance the case for curing past defaults absent supportive justifications for such a security measure. Indeed, a substantive justification for such a security measure may be the desire to combat the moral hazard of willful breaches, but that has been already discussed above. ${ }^{56}$

\section{E. Ex ante Efficiency}

An economic argument supporting the statutory requirement to cure past defaults as a precondition to the assumption of executory contracts asserts that the absence of such a requirement may lead to economic inefficiency ex ante, at the contracting stage. Forcing a party injured by a breach of contract to continue performing its obligations under the contract notwithstanding the failure to cure past defaults would entail an even greater economic risk, which parties to contracts would be forced to calculate at the contract's entrance stage. Increasing the economic risk would deter potential parties from entering into transactions carrying positive economic values or, at least, would lead the parties to demand higher consideration in exchange for third-party guarantees. This in turn would increase the transaction costs of forming contracts and impair the free flow of economic values in the market. ${ }^{57}$

Relieving the non-breaching party from its contractual obligations absent the curing of past defaults is indeed expected to reduce the cost of

55. Thomas H. Jackson \& Anthony T. Kronman, Secured Financing and Priorities Among Creditors, 88 YALE L.J. 1143 (1979); Alan Schwartz, Security Interests and Bankruptcy Priorities: A Review of Current Theories, 10 J. LEG. STUD. 1 (1981).

56. See supra Part IV.A.

57. Alan Schwartz, A Contract Theory Approach to Business Bankruptcy, 107 YALE L.J. 1807 (1998). 
this particular contractual relation. ${ }^{58}$ However, this argument ignores the impact of this rule on the cost of transactions with the debtor's other creditors. Paying pre-bankruptcy defaults to the non-debtor party awards it an individual advantage that is denied from the other creditors. As a result of this individual advantage, the other creditors experience correlative inferiority and thus will assess the concomitant cost to their contractual relations and raise their demanded contractual consideration. The costs saved in one contract are liable to be offset by the corresponding rise in costs in other contracts. In addition, paying off pre-bankruptcy claims impedes the prospects of a successful reorganization and thus may further impair the value of the other creditors' claims. Saving the costs of contractual transactions in the economy is, therefore, in doubt. Absent additional grounds, it seems that the cost of contracts argument per se is speculative at best. ${ }^{59}$

\section{Past Defaults, the Automatic Stay and PRIORITIES}

Part IV has shown that normative considerations justify the curing of past defaults as a condition precedent to the assumption of an executory contract in bankruptcy.

This part analyzes derivative matters. First, it examines the scope of the automatic stay and its logic as they relate to the continuation of an executory contract. Secondly, it discusses the appropriate timing for judicial decisions pertaining to the fate of executory contracts in bankruptcy. Finally, it calls for according judicial discretion, upon the assumption of executory contracts, to limit the non-debtor party's priority for pre-bankruptcy defaults. It argues that this priority should be respected only if that party performs in good faith prior to assumption and avoids stalling its own performance in the bankruptcy case. These matters are discussed below.

58. See also Yeon-Koo Che \& Alan Schwartz, Section 365, Mandatory Bankruptcy Rules and Inefficient Continuance, 15 J.L. ECON \& ORG. 441 (1999).

59. In the context of security interests the efficiency has been argued to be found in cost savings of monitoring debtor misbehavior or creditor misbehavior. See, e.g., Douglas G. Baird, The Importance of Priority, 82 Cornell L. REV. 1420 (1997); Frank H. Buckley, The Bankruptcy Priority Puzzle, 72 VA. L. Rev. 1393 (1986); Saul Levmore, Monitoring and Freeriders in Commercial and Corporate Settings, 92 YALE L.J. 49 (1982); Cheol Park, Monitoring and Structure of Debt Contracts, 55 J. FIN. 2157 (2000); Randal C. Picker, Security Interests, Misbehavior, and Common Pools, 59 U. CHI. L. ReV. 645 (1992); Alan Schwartz, A Theory of Loan Priorities, 18 J. LEG. STUD. 209 (1989); Alan Schwartz, The Continuing Puzzle of Secured Debt, 37 VAND. L. REv. 1051 (1984); Robert E. Scott, A Relational Theory of Secured Financing, 86 CoLuM. L. REV. 901 (1986). 


\section{A. Past Defaults and the Automatic Stay}

Executory contracts are a double-edged sword. As discussed above, ${ }^{60}$ a party to an executory contract is the only claimant of the debtor who is simultaneously also contractually bound to the debtor's future operations. The fairness argument requires reciprocity between the debtor and the nondebtor party. Yet, the prompt curing of past defaults is irreconcilable with the general policy of suspending the payment of pre-petition claims at the initial stage of the bankruptcy case and delaying the payment to later stages. $^{61}$

Fairness notwithstanding, curing past defaults upon the inception of bankruptcy would impair the fragile state of the debtor and hurt its chances to reorganize successfully. The automatic stay's purpose of facilitating a feasible reorganization of the debtor ${ }^{62}$ justifies the suspension of payments of all pre-petition claims ${ }^{63}$ until the debtor's estate is liquidated or a reorganization plan is confirmed by the court. In the early stages of the case the debtor is mostly cash-constrained. While the debtor may finance its current operations through DIP financing, ${ }^{64}$ this financing is not meant to serve as a source for paying off pre-petition claims. ${ }^{65}$

Claims arising from the non-debtor party's default on an executory contract are no exception to the general bar against paying off pre-petition claims upon the onset of bankruptcy. The future performance by the non-

60. See supra Part IV.C (2010)

61. This policy is reflected especially in the automatic stay. Bankruptcy Code $\S 362$

62. The other rationale of the automatic stay is to streamline the debtor's claims and pay them off in accord with the statutory rules of absolute priority and equality among unsecured creditors. Borman v. Raymark Indus., Inc., 946 F.2d 1031, 1036 (3d Cir. 1991); Lincoln Sav. Bank v. Suffolk County Treasurer (In re Parr Meadows Racing Ass'n, Inc.), 880 F.2d 1540, 1545 (2d Cir. 1989); Holtkamp v. Littlefield (Matter of Holtkamp), 669 F.2d 505, 508 (7th Cir. 1982).

63. The bar against paying off pre-petition claims does not differentiate between secured and unsecured claims. Bankruptcy Code $\S 362$ (a)(3)-(6) (2010). The postponement of payment applies regardless of the claim's relative priority.

64. Bankruptcy Code $\S 364$ (2010).

65. While discussing the controversial practice of cross-collateralization, George Triantis noted that "this arrangement . . . conflicts with the bankruptcy principle of equal treatment of pre-petition claimants of the same class." Triantis II, supra note 23, at 907. See also Shapiro v. Saybrook Mfg. Co. (In re Saybrook Mfg. Co.), 963 F.2d 1490, 1495 (11th Cir. 1992). This practice has been approved only as an arrangement of last resort in cases where any alternative was unavailable and absent the financing, all creditors would be worse off. See, e.g., In re Roblin Industries, Inc., 52 B.R. 241, 244 (Bankr. W.D.N.Y. 1985); In re Vanguard Diversified, 31 B.R. 364, 366 (Bankr. E.D.N.Y. 1983). It follows, then, that the use of DIP financing may not be used for the mere preferential payment of selected pre-petition claims. See also Jeff Böhm, The Legal Justifications for the Proper Use of Cross-Collateralization Clauses in Chapter 11 Bankruptcy Cases, 59 AM. BANKR. L. J. 289, 321-22 (1985); Skeel, supra note 23, at 941-42. 
debtor party ought not to disrupt the balance achieved by the automatic stay. ${ }^{66}$ Future performance should be provided by the non-debtor party even though its right to receive payments for past defaults is delayed to a later stage in the bankruptcy case. Indeed, as discussed in Part IV above, only when the contract is assumed, the non-debtor party is entitled to be paid its pre-petition claim. That is the time when the considerations of fairness and combating moral hazard are factored in, but the formal decision to assume the contract may be delayed until late in the bankruptcy case. $^{67}$

\section{B. The Timing of Judicial Determinations}

Subjecting claims for past defaults on executory contracts to the automatic stay entails a couple of legal conclusions. First, it merits a separation between the judicial inquiry concerning the provision of adequate assurance of future performance and the actual curing of past defaults. Secondly, it calls for the continuation of executory contracts upon the onset of bankruptcy, even if the decision whether to assume or reject the contract is delayed until the confirmation of a reorganization plan.

\section{Separating Assurance of Future Performance from Curing Past Defaults}

The curing of past defaults, alongside the formal decision whether to assume an executory contract, may be delayed to an advanced stage of the bankruptcy case - the confirmation of a reorganization plan. ${ }^{68}$ This stage may take place several weeks, even months, after the commencement of the bankruptcy case.

The performance of the executory contract by both sides, on the other hand, is continuous throughout the life of the contract. The non-debtor party is entitled to limit its additional exposure to non-performance by the debtor party prior to any performance on its part. ${ }^{69}$ Thus, the trustee or

66. Section 362(a)(3) of the Bankruptcy Code stays the termination of executory contracts. See, e.g., In re Circle K Corp., 190 B.R. 370, 376-77 (9th Cir. BAP 1996); In re Clearwater Natural Resources, L.P., 421 B.R. 392 (Bankr. E.D. Ky. 2009).

67. See infra Part V.B.2.

68. This rule is applicable in cases under Chapters $9,11,12$ or 13 of the Bankruptcy Code, that is, the restructuring chapters. Bankruptcy Code $\S 365(\mathrm{~d})(2)$ (2010). However, in a liquidation case under Chapter 7 of the Code, the time period for the trustee to decide whether to assume a contract or to reject it is within 60 days after the order for relief. Id. at $\S 365(\mathrm{~d})(1)$. With respect to unexpired leases of nonresidential real property, the Code sets the time limit of 60 days after the order for relief for a decision whether to assume or reject the lease in cases under all aforementioned chapters of the Code. Id. at $\S 365(\mathrm{~d})(4)$.

69. See supra text accompanying Part IV.C. 
debtor-in-possession must provide adequate assurance of future performance of the debtor's obligations under the contract immediately upon the inception of the bankruptcy case. While the curing of past defaults as a condition for assumption comes into play late in the case, securing additional performance by the non-debtor party merits assurances of reciprocal performance by the debtor party at all stages of the case. ${ }^{70}$ These two matters are dealt with separately, and the failure to provide either one should preclude the continued performance by the non-debtor party.

The Bankruptcy Code follows suit, albeit in a formally different fashion. The Code requires both the provision of adequate assurance of future performance and the cure of past defaults only as of the time of assumption of the contract. ${ }^{71}$ With respect to the pre-assumption period, the Code requires the trustee to perform all the debtor's obligations under an executory contract or unexpired lease until the assumption or rejection of that contract or lease. ${ }^{72}$ The combination of the Code's provisions leads to the desired statutory requirement - a continuous demand of undisrupted current and future performance of the debtor's contractual obligations in exchange for the ongoing non-debtor's performance.

\section{Continuation of Executory Contracts Prior to Assumption}

A second, and related, legal conclusion derived from the application of the automatic stay to claims for past defaults on executory contracts is that the continuation of the contract cannot be dependent on a prompt decision to assume the contract. While this decision is the legal trigger for paying off past defaults, the decision whether to assume or reject an

70. Adequate assurance may be provided in the form of a guarantee, or through the obtaining of DIP financing for the current expenses of the debtor.

71. Bankruptcy Code $\S 365(\mathrm{~b})(1)(\mathrm{C})$ (2010) ("[T]he trustee may not assume such contract or lease unless, at the time of assumption . . . the trustee . . . provides adequate assurance of future performance under such contract or lease" (emphasis added)).

72. Id at $\S 365(\mathrm{~d})(3)$, (10). These two subsections apply to unexpired leases of nonresidential real property and unexpired leases of personal property. It is disputable whether the statute applies similarly to unexpired leases of residential real property and executory contracts other than leases. See Robert Laurence, At Home with the Bankruptcy Code, 61 Am. BANkr. L. J. 125 (1987); Daniel Morman, Leases of Personal Property in Chapter 11 Bankruptcies - An Overview of 11 U.S.C. $\S 365(D)(10), 23-M a y$ AM. BANKR. Inst. J. 36 (2004) (exploring the history, prerequisites and applications of this statute). But see NLRB v. Bildisco \& Bildisco, 465 U.S. 513, 531 (1984) ("If the debtor-in-possession elects to continue to receive benefits from the other party to an executory contract pending a decision to reject or assume the contract, the debtor-in-possession is obligated to pay for the reasonable value of those services ... which, depending on the circumstances of a particular contract, may be what is specified in the contract." (internal citations omitted)). See also In re Mammoth Mart, Inc., 536 F.2d 950, $954-55$ (1st Cir. 1976). 
executory contract considers first and foremost the potential economic value of the contract to the debtor's business. ${ }^{73}$ Examining the overall value of a contract for the debtor's business may require time. Thus, the Code's flexibility and its grant of an extended period of time to decide whether to assume or reject the contract are correct.

It follows that, upon the inception of bankruptcy, no final and formal decision as to whether to continue the contractual relationships of the debtor will be made. Nonetheless, in order to facilitate such a decision later on, the law must limit the non-debtor's power to terminate the contract immediately due to past non-payments. ${ }^{74}$ The continuous performance of the contract is a condition precedent for any decision to assume it.

\section{Limiting the Priority of Past Defaults}

The analysis in Part IV above supported the requirement to cure past defaults prior to the assumption of an executory contract. To the extent the trustee or debtor-in-possession assumes the executory contract upon the confirmation of a reorganization plan, past defaults are to be paid ahead of other pre-petition claims. ${ }^{75}$

The Bankruptcy Code lists several priority claims ${ }^{76}$ and mandates that these claims must be paid or treated prior to the court's confirmation of a reorganization plan. ${ }^{77}$ Effectively, the requirement of curing past defaults accords the non-debtor party to an assumed executory contract a similar priority over other unsecured claims. ${ }^{78}$

73. Madlyn Gleich Primoff \& Erica G. Weinberger, E-Commerce and Dot-Com Bankruptcies: Assumption, Assignment and Rejection of Executory Contracts, 8 АM. BANKR. INST. L. REV. 307, 309 (2000) (analyzing the assumption, assignment, and rejection of licenses and agreements relating to intellectual property); Westbrook, supra note 1, at 231-32.

74. This is achieved by the automatic stay. See also supra at Part V.A.

75. See supra text accompanying Part IV.C.

76. Bankruptcy Code $\S 507$ (a) (2010).

77. Id. at $\S 1129(\mathrm{a})(9)$. Of these priorities, administrative expenses and claims arising in an involuntary case between the filing of the bankruptcy petition and the earlier of the appointment of a trustee or the order of relief must be paid in cash. Id. at $\S \S 502(\mathrm{f}), 503(\mathrm{~b})$, 507(a)(1), (2), 1129(a)(9)(A). The priority claims listed in section 507(a)(3)-(7) of the Code shall be paid in cash unless the class of claims of each such priority voted to accept the reorganization plan and the plan allocates each claimant of that class deferred cash payments of a value equal to the allowed amount of such claim. Id. at $\S 1129$ (a)(9)(B).

78. The Supreme Court regarded the cure of past defaults as an administrative expense, which is one of the various statutory priorities. See NLRB v. Bildisco \& Bildisco, 465 U.S. $513,531-32$. If defaults are not cured promptly upon assumption, they nonetheless receive the prioritized status of administrative expense. In re America the Beautiful Dreamer, Inc. (as yet unpublished), 46 BANKr. Ct. Dec. 174, 3-4 (2006). See also Brian Leepson, A Case for the Use of a Broad Court Equity Power to Facilitate Chapter 11 Reorganization, 12 BANKR. DEV. J. 775 (1996) (exploring the way the Bankruptcy Code is to balance competing 
I propose conditioning the priority payments of past defaults on the non-debtor good faith performance. This would create a constructive lever for securing the cooperation of the non-debtor party in performing the executory contract. By operation of bankruptcy law, the non-debtor party must continue performing its obligations under the contract throughout the case. As discussed earlier, its power to terminate the contract upon the inception of bankruptcy has been justifiably curtailed. ${ }^{79}$ Nonetheless, the non-debtor party may stall its performance, disrupt the ordinary course of the debtor's business, and adversely affect the latter's reorganization efforts. ${ }^{80}$

Bankruptcy law should be amended to confer discretion to the bankruptcy courts to disallow the priority benefit for past defaults. The court may disallow this priority in circumstances where it is convinced that the non-debtor party, despite being provided assurance of future performance, failed to perform in good faith its obligations under the contract. Any delay tactics or other non-cooperative behavior by the nondebtor party may backfire and leave it with only an unsecured claim for the debtor's pre-petition defaults. ${ }^{81}$

This proposed amendment shall limit the non-debtor party's rights at the back-end of the bankruptcy case. Such limitation can serve as a selfenforcing measure that will encourage the non-debtor party to perform and cooperate with the debtor in good faith. By no means does this proposed limitation impair the non-debtor party's rights. To the extent it performs its contractual obligations, it shall receive full payment of past defaults. Hence, the proposed amendment is both fair to the non-debtor party and incentivizes it to continue the executory contract without creating artificial intervals. This proposal is likely to further facilitate successful

debtor-creditor interests); Yaad Rotem, Pursuing Preservation of Pre-Bankruptcy Entitlements: Corporate Bankruptcy Law's Self-Executing Mechanisms, 5 BERKELEY Bus. L. J. 79, 103-104 (2008) (arguing for a rigid time frame cap on reorganizations); Charles J. Tabb, Emergency Preferential Orders In Bankruptcy Reorganizations, 65 AM. BANKR. L.J. 75 (1991) (studying the problem of emergency orders entered early in Chapter 11 reorganizations).

79. See supra at Parts III, IV.

80. See e.g. Bussel \& Klee, supra note 1515, at 719; John T. Gregg, Compelling NonDebtor Suppliers to Perform under Executory Contracts, 27-6 AM. BANKR. INST. J. 20 (June 2008) (describing the factors compelling non-debtor suppliers to perform); Triantis I, supra note 3 , at 700-02 (discussing possible motives for non-compliance with the contractual terms).

81. Similarly, to the extent the non-debtor party's behavior shall frustrate the performance of the executory contract and hence the ability of the trustee or debtor-inpossession to assume the contract, the non-debtor party risks ending up as a mere unsecured claimant based on the debtor's pre-petition breaches of the contract. Any executory contract not assumed is deemed rejected. Bankruptcy Code $\S 365(\mathrm{~d})(1)$, (4) (2010). A claim of a non-debtor party to a rejected executory contract based on the debtor's pre-petition defaults constitutes an unsecured claim. Id. at $\S 365(\mathrm{~g})$. 
reorganizations.

\section{CONCLUSION}

This paper analyzed the contours of assumption of an executory contract in bankruptcy. Particularly, it questioned the justification for the rescission remedy with respect to such contracts.

The paper has shown that the two primary justifications for rescission in contract law, preventing recurring breaches and ex ante deterrence of potential breachers, lose force in bankruptcy. The operational environment in bankruptcy reduces the concern of recurring breaches. As for deterrence, in a creditor-friendly bankruptcy regime, pre-bankruptcy defaults on a contract are likely to be no-fault, insolvency-related defaults, against which deterrence is irrelevant. In a debtor-friendly bankruptcy regime, breaches may be either no-fault breaches or willful breaches. Given, however, the rigid, irreversible nature of termination on one hand and the economic importance of executory contracts to reorganization on the other, the paper argued in favor of a softer remedy.

The soft alternative for termination is the assumption of the contract, despite its breach, provided that upon assumption the debtor cures its prebankruptcy defaults. The paper has shown that in addition to its constructive role of combating willful breaches, curing past defaults is fair to the non-debtor party and consistent with the distribution rules of bankruptcy.

The paper supported the Bankruptcy Code's policy of subjecting claims for pre-bankruptcy defaults on executory contracts to the automatic stay until the later assumption of the contract. It further proposed that the non-debtor's right to full payment of past defaults upon assumption of the contract be subject to judicial discretion in circumstances where that party stalled its performance in bad faith and hurt the debtor's reorganization efforts. 